\title{
Agricultural abandonment in Mediterranean reclaimed peaty soils: long-term effects on soil chemical properties, arbuscular mycorrhizas and $\mathrm{CO}_{2}$ flux
}

\author{
Elisa Pellegrino ${ }^{\mathrm{a}, 1, *}$, Simona Bosco ${ }^{\mathrm{a}, 1}$, Valentina Ciccolini ${ }^{\mathrm{a}, 1}$, Chiara Pistocchi ${ }^{\mathrm{a}, \mathrm{b}}$, \\ Tiziana Sabbatini ${ }^{a}$, Nicola Silvestri ${ }^{c}$, Enrico Bonari $^{\mathrm{a}}$ \\ a Institute of Life Sciences, Scuola Superiore Sant'Anna, P.za Martiri della Libertà 33, 56127 Pisa, Italy \\ ${ }^{\mathrm{b}}$ Group of Plant Nutrition, USYS ETH Zurich, Eschikon 33 Lindau, Switzerland \\ ${ }^{\mathrm{c}}$ Department of Agriculture, Food and Environment, University of Pisa, Via del Borghetto 80, 56124 Pisa, Italy
}

\section{A R T I C L E I N F O}

\section{Article history:}

Received 31 March 2014

Received in revised form 6 September 2014

Accepted 9 September 2014

Available online $\mathrm{xxx}$

\section{Keywords:}

Peat soil

Soil quality

Land use change

Arbuscular mycorrhizal fungi (AMF)

Soil $\mathrm{CO}_{2}$ flux

Soil respiration partitioning

\begin{abstract}
A B S T R A C T
In the last century, most peatlands were reclaimed for agricultural purposes, which led to peat degradation and to severe subsidence, and thus too wet conditions for crops. In some areas this has therefore led to wide agricultural abandonment. However, studies on the effect of agricultural abandonment as a potential restoration tool are lacking. In this study, the effectiveness and the restoration potential of agricultural abandonment in reducing peat degradation and in improving soil microbial biodiversity were evaluated. The main chemical parameters, arbuscular mycorrhizal (AM) fungal diversity and soil respiration partitioning were used to assess the long-term effect of 15 years of agricultural abandonment (Aband) in a Mediterranean reclaimed peatland. An intensive maize cultivation (Cult) in the same area was used as a comparison. Multivariate analyses showed that 15 years of agricultural abandonment: did not affect the main soil chemical parameters, except for $\mathrm{NH}_{4}{ }^{+}$which was lower in the Aband than in the Cult; increased AM fungal root colonization and the diversity in terms of number of families of AM fungi retrieved in roots, but decreased soil AM fungal richness; reduced total soil respiration and its autotrophic component but increased respiration by heterotrophs; determined a lower fluctuation of soil $\mathrm{CO}_{2}$ flux response to air temperature than the Cult. Thus, although some soil quality parameters were significantly improved, 15 years of agricultural abandonment may not lead to an effective restoration. Consequently, alternative and sustainable solutions for the protection and preservation of Mediterranean peatlands need to be developed.
\end{abstract}

(c) 2014 Elsevier B.V. All rights reserved.

\section{Introduction}

Wetlands are species-rich habitats performing valuable ecosystem services such as flood protection, water quality enhancement and carbon (C) sequestration. Their protection is officially a priority for 168 nations that have ratified the Ramsar Convention (Verhoeven and Setter, 2010). These habitats cover about $6 \%$ of the global surface area and about $60 \%$ are represented by peatlands, which play an important role in the global C cycle as a long-term sink. In Europe peatlands cover about $20 \%$ of the land area. Although most are located in northern Europe, some small sites are also situated in the Mediterranean area (Montanarella et al., 2006).

\footnotetext{
* Corresponding author. Tel.: +39 050 883181; fax: +39 050883526.

E-mail address: e.pellegrino@sssup.it (E. Pellegrino).

1 These authors contributed equally to this work.
}

In the last 200 years, most peatlands have been reclaimed in Europe for agricultural purposes because of their natural fertility, which has thus destroyed their original character and ecological functions (Verhoeven and Setter, 2010). The increase in aerobic conditions due to the reclamation and agricultural practices led to significant increases in soil organic matter (SOM) oxidation. Major consequences included the high release of carbon dioxide $\left(\mathrm{CO}_{2}\right)$, nutrient losses to water bodies, biodiversity losses and degradation of the peat with a drastic decrease in soil quality together with a severe subsidence which led in some areas to conditions that are too wet for crops.

Soil quality can be evaluated using chemical, biochemical and biological indicators (Doran and Parkin, 1996). Within the chemical and biochemical parameters of soil, SOM and soil respiration are the main and most suitable indicators to measure $C$ storage and degradation. As regards soil respiration, $\mathrm{CO}_{2}$ flux is considered as a proxy for SOM decomposition and its partitioning between the 
microbial and the root component is required in order to identify $\mathrm{CO}_{2}$ sources and to calculate their contribution to the total flux (Kuzyakov, 2006). In addition, in order to assess soil health and functioning, an evaluation of the diversity of beneficial microbes such as arbuscular mycorrhizal (AM) fungi is valuable since these fungi are involved in plant growth and nutrient uptake enhancement and in improving soil structure (Smith and Read, 2008).

Several studies have investigated the soil quality degradation of reclaimed peatlands intensively used for agriculture. Numerous strategies have been proposed for their restoration, such as the rewetting with or without the introduction of plant species, and a shift to extensive-grazing systems or to less intensive agriculture use (Pfadenhauer and Grootjans, 1999; Zeitz and Velty, 2002). In the agricultural peatlands where none of these strategies have been adopted, the subsidence and consequent inability to support crop growth have led to the massive abandonment of the areas (Joosten and Clarke, 2002).

However, studies are lacking on the effect of the agricultural abandonment in reclaimed peatlands, and in particular on the most vulnerable Mediterranean areas where climatic conditions favor a rapid mineralization of the SOM. Therefore, the effectiveness and the restoration potential of the agricultural abandonment in reducing the peat degradation and in improving soil microbial biodiversity need to be evaluated.

We assessed the long-term effect of 15 years of agricultural abandonment on the soil quality of a Mediterranean reclaimed peatland located in the Massaciuccoli Lake basin (Tuscany, Italy). To this end, chemical parameters, AM fungal molecular diversity and community structure, and in situ soil respiration partitioning were used. The agricultural abandonment was compared with an intensively cultivated peaty soil represented by a continuous maize (Zea mays L.) cropping system, which is the main system in the area (Silvestri et al., 2012).

\section{Materials and methods}

\subsection{Field site}

The experimental site is situated in the south of the Massaciuccoli Lake basin $\left(43^{\circ} 49^{\prime} \mathrm{N}-10^{\circ} 19^{\prime} \mathrm{E}\right)$ within the natural park of Migliarino-San Rossore-Massaciuccoli (Pisa, Italy). Since 1930 , most of the basin has been drained by a complex network of artificial canals, ditches and pumping stations. This has forced water from reclaimed areas into the lake, causing a severe subsidence ranging from 3 to $4 \mathrm{~cm}_{\text {year }}{ }^{-1}$, caused by compaction and peat oxidation (Pistocchi et al., 2012). The soil was classified as Histosol according to the USDA system (Soil Survey Staff, 1975) and as Rheic Histosol according to the FAO system (IUSS, 2006). The thickness of the organic horizon is about $3 \mathrm{~m}$ (from 2 to $4 \mathrm{~m}$ ) with a SOM content of $29.2 \%$ (minimum $20.1 \%$-maximum $55.4 \%$ (Walkley-Black)), a clay content of $25 \%$, a pH of 4.9 , a bulk density of $0.5 \mathrm{~g} \mathrm{~cm}^{-3}$ in the $0-30 \mathrm{~cm}$ depth layer. Therefore, these organic soils can be defined also as peat and peaty soil (IPCC, 2006).

During the year the water table is maintained by pumping stations at a quite stable level, ranging from 0.40 to $0.60 \mathrm{~m}$ (Pistocchi et al., 2012). Therefore, the upper soil layer is only occasionally subjected to water saturation. The climate is Mediterranean (Csa) according to the Köppen-Geiger climate classification map (Kottek et al., 2006). Summers are dry and hot, rainfall is mainly concentrated in autumn and spring (mean annual rainfall ca. $945 \mathrm{~mm}$ year $^{-1}$ ) and mean monthly air temperature at $2 \mathrm{~m}$ ranging from $7{ }^{\circ} \mathrm{C}$ in February to $30^{\circ} \mathrm{C}$ in August (with a mean of $14.8^{\circ} \mathrm{C}$ year $^{-1}$ ). Average monthly maximum, mean and minimum temperatures and rainfalls over the period 1990-2012, recorded at a weather station located in the Massaciuccoli basin are shown in Fig. S1. The site was cultivated with maize until
15 years ago when agricultural practices were abandoned in an area of about 15 ha and the natural succession vegetation were left to develop. The surrounding area (about $15 \mathrm{ha}$ ) is still cultivated with maize.

\subsection{Experiment 1: effect of agricultural abandonment on chemical parameters, root traits and AM fungi}

The aim of this experiment was to evaluate the long-term effect of the abandonment of agricultural practices compared to maize cultivation in terms of chemical soil parameters, root traits, such as the root biomass and AM fungal colonization, and AM fungal diversity and community structure.

\subsubsection{Experimental set-up}

The experiment was a completely randomized design with land use as treatment and three replicates $(n=3$; field replicates of 0.7 ha) (Fig. S2). We had six cases (field replicates), three of them of one land use and another three of the other land use. At the beginning, before the experiment started, fields looked all the same and we had numbered them 1-6 and let a random number generator to pick the three fields that received same treatment. The first land use type was an agricultural peaty soil left abandoned for 15 years (Aband). Field replicates were left to develop under the natural succession vegetation. A floristic survey showed that the most common species were Abutilon theophrasti L., Amaranthus retroflexus L., Arctium lappa L., Artemisia sp., Atriplex sp., Bidens sp., Biphora sp., Calystegia sp., Datura stramonium L., Echinochloa crusgalli L., Galium sp., Humulus lupulus L., Linaria sp., Phragmites australis L, Typha latifolia L., Lythrum salicaria L., Phytolacca americana L., Rumex crispus L., Silene alba L. and Xanthium sp. The most abundant plant species were Calystegia sp. (17.5\%), P. australis (15\%), A. lappa (13.8\%) and B. tectorum (13.8\%). No fertilizers or other agricultural practices were applied, except for an annual vegetation cutting at the end of the winter season.

The second land use type was an intensively cultivated peaty soil represented by continuous maize (Cult). Each year in late spring field replicates were ploughed $(30-35 \mathrm{~cm})$ and harrowed, as the main and secondary tillage, respectively. Maize was sown at the beginning of June at a rate of 75,000 seeds ha ${ }^{-1}$ with $75 \times 17 \mathrm{~cm}$ row spacing and harvested in late September. Fertilization was applied at sowing and at mechanical weeding with rates of $32 \mathrm{~kg} \mathrm{ha}^{-1} \mathrm{~N}, 96 \mathrm{~kg} \mathrm{ha}^{-1} \mathrm{P}, 96 \mathrm{~kg} \mathrm{ha}^{-1} \mathrm{~K}$ and $138 \mathrm{~kg} \mathrm{ha}^{-1} \mathrm{~N}$, respectively. Chemical and mechanical post-emergence weed controls were applied. The fifteen year average maize yield was $6.4 \mathrm{tha}^{-1}$.

\subsubsection{Sampling}

In July 2011 one combined soil sample, resulting from pooling seven soil cores, was collected from each field replicate $(0-30 \mathrm{~cm}$ depth) in order to cover chemical and AM fungal spatial variability. Sampling was carried out only once in July, since mid-summer is the best choice because sampling should not be close to soil treatments and because the variability in chemical parameters changes slightly during the year (Pellegrino et al., 2011). These facts, along with the fact that AM fungi consistently maintain the same patterns of variability in differently managed systems, although with seasonal changes, were taken into account when choosing July as a single sampling time (Vandenkoornhuyse et al., 2002; Oehl et al., 2010; Di Bene et al., 2013).

Soil samples used for the chemical parameter determinations were oven dried at $60^{\circ} \mathrm{C}$ and then sieved at $2 \mathrm{~mm}$, while for genomic DNA extraction roots were carefully plucked with forceps. Soil DNA extracts were stored at $4{ }^{\circ} \mathrm{C}$. As regards the root trait determinations, seven turfs were extracted $(20 \mathrm{~cm}$ depth) from each field replicate and then combined. In the laboratory, roots were collected from each combined sample, then washed and 
dried at $60^{\circ} \mathrm{C}$ for root dry weight (DW) measurements, whereas for AM fungal root colonization assessment and genomic DNA extraction, root subsamples were taken and stored at $4{ }^{\circ} \mathrm{C}$.

\subsubsection{Soil chemical analyses}

Soil samples were analyzed for: pH; electrical conductivity, EC; exchangeable potassium, $K_{\text {exch }}$; total nitrogen, $N_{\text {tot }}$; ammonium, $\mathrm{NH}_{4}{ }^{+}$; nitrates, $\mathrm{NO}_{3}{ }^{-}$; soil organic matter, SOM; total phosphorus, $P_{\text {tot }}$; available phosphorus, $P_{\text {avail }}$ and organic phosphorus, $P_{\text {org }}$. Soil $\mathrm{pH}$ and EC were measured in deionized water $(1: 2.5$ and $1: 2, \mathrm{w} / \mathrm{v}$, respectively). $K_{\text {exch }}$ was determined by atomic absorption. $P_{\text {tot }}$ and $P_{\text {avail }}$ were determined by colorimetry using perchloric acid digestion and an extraction with sodium bicarbonate, respectively (Olsen and Sommers, 1982). $P_{\text {org }}$ was evaluated using the Metha extraction (Hence and Anderson, 1962). $N_{\text {tot }}$ was determined by the macro Kjeldahl digestion procedure, while $\mathrm{NO}_{3}{ }^{-}$and $\mathrm{NH}_{4}{ }^{+}$were determined by the Kjeldahl method after $\mathrm{KCl} 2 \mathrm{~N}$ extraction and, in the case of $\mathrm{NO}_{3}{ }^{-}$, after reduction with Devarda's alloy. SOM was measured using the modified Walkley-Black wet combustion method (Nelson and Sommers, 1982). Soil C/N ratio was calculated by dividing SOC $((\mathrm{SOM} / 1.7) \times 10)$ by total $\mathrm{N}$.

\subsubsection{Root determination and AM fungal root colonization}

From the combined turfs of each field replicate, soil subsamples (mean soil DW ca. $400 \mathrm{~g}$ ) were used to determine root DW. Roots were manually collected with forceps and washed by wet-sieving and decanting down to a mesh size of $250 \mu \mathrm{m}$. After removing organic debris, all live and dead root fragments were oven-dried and weighed to determine root DW. Root DW per gram of soil was calculated.

AM fungal root colonization was assessed under a stereomicroscope (Olympus SZX 9, Olympus Optics, Tokyo, Japan), after clearing and staining with lactic acid instead of phenol (Phillips and Hayman, 1970), following the gridline intersect method (McGonigle et al., 1990). The roots were mounted on microscope slides and examined at magnifications of $125-500$, and verified at a magnification of 1250 .

\subsubsection{AM fungal diversity: extraction of genomic DNA, PCR amplification, cloning and sequencing}

Soil DNA was extracted from $0.5 \mathrm{~g}$ of soil using the PowerSoil ${ }^{\mathbb{R}}$ MoBio kit (Mo Bio Laboratories Inc., NY, USA) $(n=6)$, while root DNA was extracted from 100-mg fresh root samples using the DNeasy ${ }^{\circledR}$ Plant Mini Kit $(n=6)$ (Qiagen, Germantown, MD, USA). DNA quality was checked on a ND-1000 spectrophotometer (NanoDrop Technology, Wilmington, DE). The direct extraction of the DNA from soil was performed to prevent the host preference effect as previously described by Davison et al. (2012). PCR amplification was performed using the primer pair NS31 and AM1 targeting the small subunit ribosomal RNA (SSU rRNA) region (Simon et al., 1992; Helgason et al., 1998). Although longer and higher discriminating regions are available (Krüger et al., 2012; Pellegrino et al., 2012), the NS31/AM1 SSU region was targeted because most Glomeromycota diversity data are obtained using this region, which provides a larger comparative DNA sequence data-set.

PCR was performed using the temperature profile described by Helgason et al. (1998). No PCR inhibition problems were registered. PCR amplicons were generated from $10 \mathrm{ng} \mu \mathrm{L}^{-1}$ genomic DNA in volumes of $20 \mu \mathrm{L}$ with $0.5 \mathrm{U}$ of GoTaq ${ }^{\mathbb{R}}$ hot start polymerase (Promega Corporation, Madison, WA, USA), $0.2 \mu \mathrm{M}$ of each primer (NS31/AM1), $0.2 \mathrm{mM}$ of each dNTP, $1.25 \mathrm{mM}$ of $\mathrm{MgCl}_{2}$ and $1 \mathrm{x}$ reaction buffer, using the $\mathrm{S} 1000$ Thermal $\mathrm{Cycler}^{\mathrm{TM}}$ (BIORAD, USA).

Before ligation, the quantity and quality of the PCR amplicons were checked by a spectrophotometer (NanoDrop Technology, Wilmington, DE). The PCR amplicons were then ligated into the
pGem ${ }^{\circledR}$-T Easy vector (Promega Corporation, Madison, WA, USA) and used to transform XL10-Gold ${ }^{\mathbb{R}}$ Ultracompetent Escherichia coli cells (Stratagene ${ }^{\circledR}$, La Jolla, CA, USA). At least 25 recombinant clones per amplicon library $(n=12)$ were screened for the c. 550bp-long NS31/AM1 fragment on agarose gels.

A total of 270 PCR products obtained from clones (a mean of 23 per library) were sequenced using the NS31/AM1 primers in an ABI Prism ${ }^{\circledR}$ 3730XL automated sequencer (Applied Biosystem, Foster City, CA, USA) at the High-Throughput Genomics Unit (Seattle, WA, USA).

\subsection{Experiment 2: effect of agricultural abandonment on soil $\mathrm{CO}_{2}$ flux}

The aim of this experiment was to evaluate the long-term effect of agricultural abandonment compared with maize cultivation on total soil respiration flux and autotrophic and heterotrophic $\mathrm{CO}_{2}$ flux components.

\subsubsection{Experimental set-up and sampling}

The experimental design was as described above for experiment 1. Six experimental blocks (one for each field replicate) were established for soil respiration monitoring (Fig. S3 a,b). Six blocks were considered as an adequate number due to the texture homogeneity of the mineral component of the soil (Table S1). Blocks were located about $300 \mathrm{~m}$ apart. In each field plot, the block consisted of two 20-cm diameter open-ended PVC collars: a surface collar $(7.0-\mathrm{cm}$ deep collar inserted $1 \mathrm{~cm}$ into the soil) pressed firmly onto the shallow surface layer without cutting any roots (Fig. S3a); a 25-cm deep collar inserted $20 \mathrm{~cm}$ into the soil (Fig. S3b). The collar depth was evaluated as being appropriate to exclude $90 \%$ of fine roots from the soil volume (Heinemeyer et al., 2007). Plants inside the collars were removed, leaving the root systems intact. The surface and the deep collars provided a measure of the total soil respiration (Rs) and of the respiration by heterotrophs (Rh, soil microorganisms and mesofauna), respectively (Heinemeyer et al., 2007, 2011). These measurements were used to calculate the contribution of the root component defined as respiration by autotrophs $(\mathrm{Ra}=\mathrm{Rs}-\mathrm{Rh})$.

Soil $\mathrm{CO}_{2}$ flux was measured using a non-steady-state throughflow chamber equipped with a portable infrared gas analyzer (IRGA) (Licor LI-820) connected to a steel chamber with a headspace volume of $6186 \mathrm{~cm}^{3}$ (chamber B, West Systems Srl, Pontedera, Italy). To guarantee a tight seal with the collars, the chamber had a rubber ring that fits into the collar lip. The $\mathrm{CO}_{2}$ concentration was measured per second, while the increase in the headspace $(\mathrm{ppm} / \mathrm{s})$ was checked for linearity for a period of

Table 1

Soil chemical parameters $(0-30 \mathrm{~cm}$ depth) of abandoned agricultural peaty soils (Aband) and of a maize cultivation (Cult).

\begin{tabular}{lll}
\hline Chemical parameters & Aband & Cult \\
\hline $\mathrm{pH}^{*}$ & $5.3 \pm 0.4^{* *}$ & $4.6 \pm 0.1$ \\
$\mathrm{EC}\left(\mathrm{mS} \mathrm{cm}^{-1}\right)$ & $0.9 \pm 0.1$ & $1.8 \pm 0.9$ \\
$K_{\text {exch }}\left(\mathrm{mg} \mathrm{kg}^{-1}\right)$ & $560.0 \pm 84.6$ & $397.0 \pm 51.9$ \\
$N_{\text {tot }}\left(\mathrm{g} \mathrm{kg}^{-1}\right)$ & $11.8 \pm 1.2$ & $13.0 \pm 2.2$ \\
$\mathrm{NO}_{3}-\left(\mathrm{mg} \mathrm{kg}^{-1}\right)$ & $59.0 \pm 18.6$ & $42.3 \pm 15.7$ \\
$\mathrm{NH}_{4}^{+}\left(\mathrm{mg} \mathrm{kg}^{-1}\right)$ & $56.3 \pm 4.5 \mathrm{a}$ & $148.0 \pm 9.6 \mathrm{~b}$ \\
$\mathrm{SOM}(\%)$ & $28.3 \pm 4.6$ & $25.7 \pm 4.1$ \\
$\mathrm{C} / \mathrm{N}$ & $13.7 \pm 1.0$ & $11.5 \pm 0.3$ \\
$P_{\text {tot }}\left(\mathrm{mg} \mathrm{kg}^{-1}\right)$ & $2846.7 \pm 229.2$ & $2709.0 \pm 329.3$ \\
$P_{\text {avail }}\left(\mathrm{mg} \mathrm{kg}^{-1}\right)$ & $76.3 \pm 13.6$ & $70.3 \pm 7.9$ \\
$P_{\text {org }}\left(\mathrm{mg} \mathrm{kg}^{-1}\right)$ & $2054.7 \pm 198.1$ & $2153.3 \pm 363.4$ \\
\hline
\end{tabular}

EC: electrical conductivity; $K_{\text {exch }}$ : exchangeable potassium; $N_{\text {tot }}$ : total nitrogen $\mathrm{NO}_{3}{ }^{-}$: nitrate; $\mathrm{NH}_{4}{ }^{+}$: ammonium; SOM: soil organic matter; $\mathrm{C} / \mathrm{N}$ : carbon/nitrogen ratio; $P_{\text {tot }}$ : total phosphorus; $P_{\text {avail }}$ : available phosphorus; $P_{\text {org }}$ : organic phosphorus.

Values are means \pm SE of three field replicates for each treatment. Values in the same row followed by different letters are statistically different between land uses according to ANCOVA $(P<0.05)$. 
2-3 min, and calculated and recorded in the field by a palm top computer connected via Bluetooth. $\mathrm{CO}_{2}$ flux was calculated by performing linear regressions on the logged $\mathrm{CO}_{2}$ data $\left(R^{2}>0.95\right)$, which were corrected for atmospheric pressure and air temperature. An internal fan maintained the homogeneity of the air mixture within the chamber during the measurements. Soil moisture and temperature were recorded at each measurement next to each collar by a probe (Decagon Devises $\mathrm{ECH}_{2} \mathrm{O}-\mathrm{TE} / \mathrm{EC}-\mathrm{TM}$ ) inserted into a soil depth of $5 \mathrm{~cm}$.

In 2012 monitoring was undertaken between 14 May and 13 August with a measurement frequency of once or twice per week (a total of 21 measurements per block). The sampling period was chosen by taking into consideration that in order to evaluate the impact of a land use change on soil biochemical parameters, it is necessary to sample at a much later date from soil treatments (Picci and Nannipieri, 2002). Daily mean temperatures and rainfalls during the sampling period (from May to August 2012) were recorded (Fig. 3a). Measurements were taken between 8 a.m. and 12 a.m., because mid-day values of $\mathrm{CO}_{2}$ flux are assumed to be representative of a daily average flux (Davidson et al., 1998; Luo and Zhou, 2006). Sampling started ten days after collar insertion, which is a sufficient time lapse to allow for considerable root death and to exclude the Ra component from deep collar.

\subsubsection{Modeling the soil respiration}

The cumulated Rs and Rh (from 14 May to 13 August 2012) were calculated using the exponential relationship between soil $\mathrm{CO}_{2}$ flux and air temperature. The Van't Hoff empirical exponential equation (Q10), a simplified version of the Rothamsted Carbon Model (RothC), with temperature as an independent variable (Coleman and Jenkinson, 1999) and the Lloyd and Taylor (LT) (Lloyd and Taylor, 1994) models were used in order to assess the sensitivity of soil respiration to air temperature. The three models were fitted on the measured soil $\mathrm{CO}_{2}$ flux of Rs and $\mathrm{Rh}$ for both land uses, and were then correlated with air temperature.

The performance of the three models of $\mathrm{CO}_{2}$ flux response to air temperature was evaluated using the Akaike information criterion (AIC); the root mean squared error (RMSE) and the adjusted R-square value (Rsd. ad). The best statistical fit was chosen to calculate the cumulative flux.

\subsection{Data and sequence analysis}

An updated AM fungal reference dataset of 59 NS31/AM1 public sequences (ca. $550 \mathrm{bp}$ ) was created using only morphotype sequences, including the majority of the AM fungal species listed in Schüßler and Walker (2010) phylotaxonomic classification (this alignment is in an open-access database https://sites.google.com/ site/restomedpeatland/microbiology). The reference dataset and their correspondence with the closest (similarity higher than 99\%) virtual taxon (VT) after blast search against the MaarjAM database (Öpik et al., 2010) is shown in Fig. S4 and Table S2. The AM fungal reference dataset was used for the further alignment of the newlygenerated sequences using Bioedit (Hall, 1999), after having checked the quality of their electropherograms by Vector NTI

\section{Table 2}

Root dry weight and arbuscular mycorrhizal (AM) fungal root colonization of the natural succession vegetation and of the maize occurring in abandoned agricultural peaty soils (Aband) and in a maize cultivation (Cult), respectively.

\begin{tabular}{lll}
\hline Parameters & Aband & Cult \\
\hline Root dry weight $\left(\mathrm{mg} \mathrm{g}^{-1}\right.$ soil) & $1.1 \pm 0.5^{*}$ & $0.6 \pm 0.2$ \\
AM fungal root colonization (\%) & $33.2 \pm 2.0 \mathrm{~b}$ & $22.2 \pm 1.7 \mathrm{a}$ \\
\hline
\end{tabular}

" Values are means \pm SE of three field replicates for each treatment. Values in the same row followed by different letters are statistically different between land uses according to ANCOVA $(P<0.05)$.
Advance 10 (Invitrogen, USA) and affiliation to the Glomeromycota using a basic local alignment search tool (BLAST) search (Altschul et al., 1997). An alignment of a total of 195 sequences (21 from the reference dataset, 13 from NCBI after blast search (similarity higher than 99\%), 160 newly generated sequences and the Corallochytrium limacisporum sequence L42528 as the outgroup) was trimmed to the same length (ca. $490 \mathrm{bp}$ ) and manually refined. Phylogenetic trees were inferred by the neighbor-joining ( $\mathrm{NJ}$ ) analysis using MEGA version 5.1 (Tamura et al., 2011 http://www.megasoftware. net) and the Kimura 2-parameter model (Kimura, 1980). Branch support values correspond to 1000 bootstrap replicates. The phylograms were drawn by MEGA 5.1 and edited by Adobe Illustrator CS6.

The phylogram was used to assign the newly-generated AM fungal sequences to molecular operational taxonomic units (MOTUs) on the basis of a bootstrap value of 75 . In addition, the correspondence of each MOTU with the closest VT (Öpik et al., 2010) was computed. AM fungal MOTU richness and the Shannon index $\left(H^{\prime}\right)$ were calculated using Primer v6 (Clarke and Gorley, 2006 http://www.primer-e.com). The suitability of the AM fungal community sampling was verified by Coleman rarefaction curves (Coleman, 1981) in EstimateS version 9.1 (Colwell, 2013 http://purl. oclc.org/estimates) using individual-based rarefaction curves (Gotelli and Colwell, 2001) with clones/sequences considered as units of replication.

All newly-generated sequences were submitted to the EMBL nucleotide sequence database (http://www.ebi.ac.uk/embl/) and are available under accession numbers HG425705-HG425864.

To compensate the scarce interspersion of the field replicates generated by our randomization and to prove that the effects that we detected were unlikely to have been caused by a purely spatial phenomenon, we accounted for plot positions by applying the analysis of covariance (ANCOVA). Land use was used as fixed factor and the spatial coordinates of the plots (latitude/longitude) as covariables. Therefore, we factored out the distance variable that may affect the studied dependent variables, allowing a proper comparison of the treatments. Spatial coordinates were first transformed into radiants and then standardized. All the dependent variables were log- or arcsin-transformed when necessary to fulfill the assumption for the ANCOVA. When the assumptions for the ANCOVA were not fulfilled, even after the appropriate transformation, data were analyzed using the MannWhitney non-parametric test or the Kruskal-Wallis $\mathrm{H}$ nonparametric test, followed by the Mann-Whitney test. All these analyses were performed in SPSS version 21.0 (SPSS Inc., Chicago, IL, USA).

Constrained ordination analyses (partial redundancy analysis, pRDA) were used to investigate the influence of the different land uses (used as explanatory variables) on the chemical, root and $\mathrm{CO}_{2}$ parameters and on the AM fungal relative abundances of MOTUs (used as response variables) accounting for the spatial coordinates of the plots (used as covariables). In partial constrained analysis, information that can be explained by the covariables is first extracted and then the explanatory variables are used to "explain" the residual variation. RDAs were used to assess the influence of different matrices (roots and soil) on the explanatory variables. RDA linear method (Lepš and Šmilauer, 2003) was used since the gradient of the detrended correspondence analysis was lower than four. All data were log-transformed, centered and standardized by the response variables. Monte Carlo permutation tests were performed using 499 random permutations (unrestricted permutation) in order to determine the statistical significance of the relations between land use and response variables. RDAs and pRDAs were performed by Canoco for Windows v. 4.5 (ter Braak and Šmilauer, 2002). The biplots were drawn by CanoDraw for Windows. 


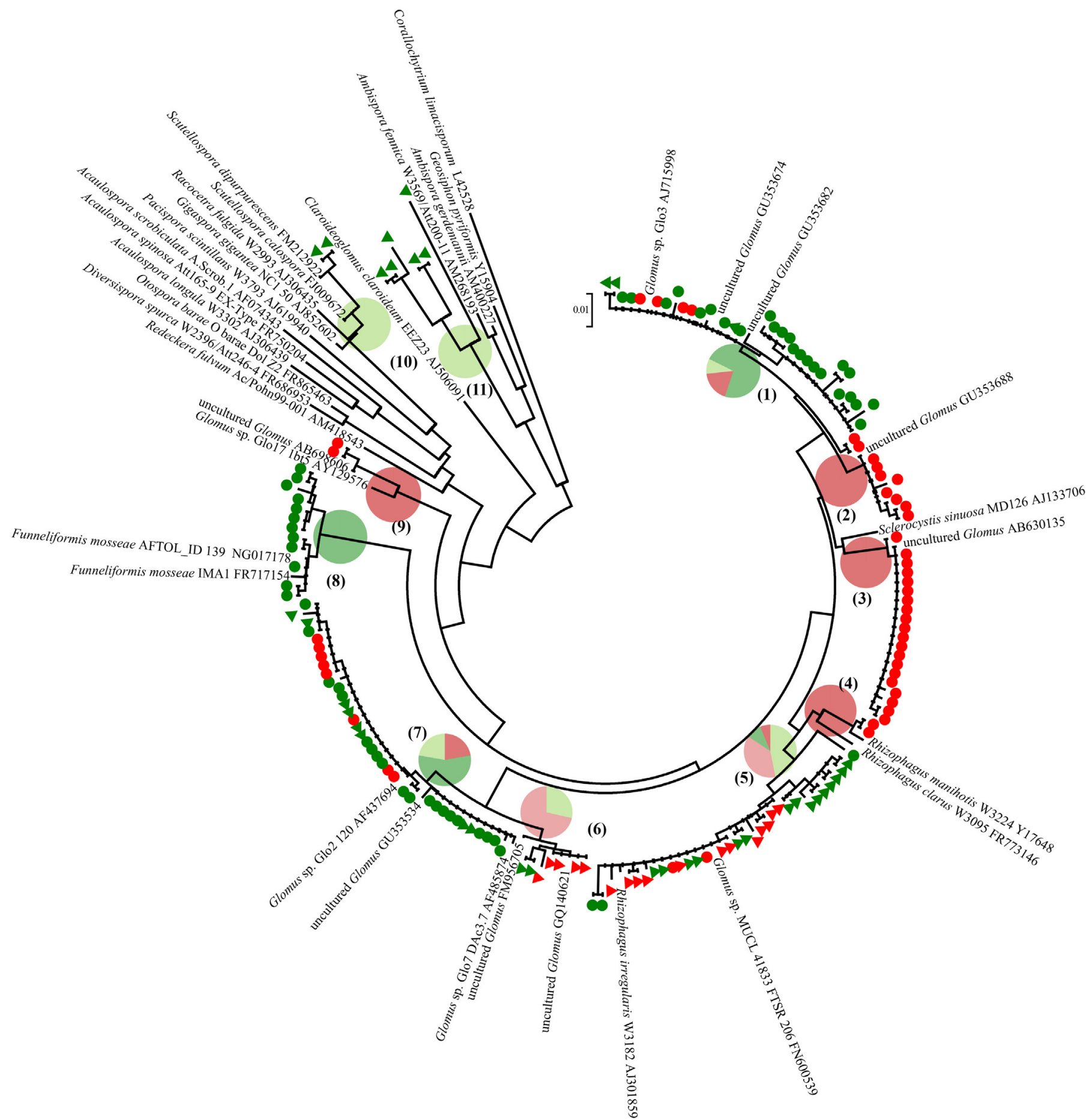

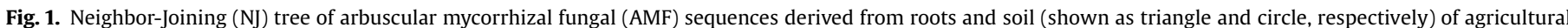

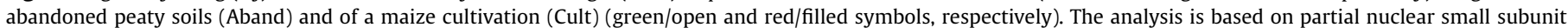

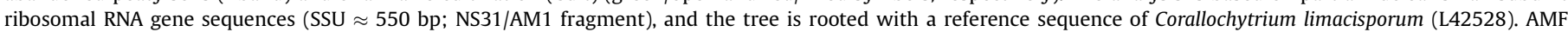

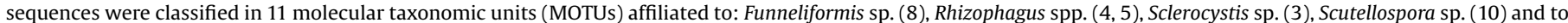

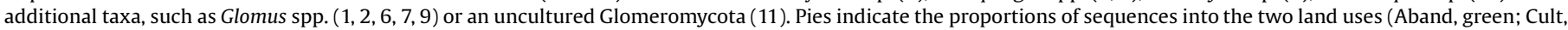

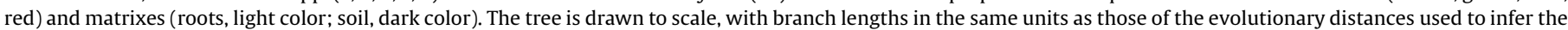

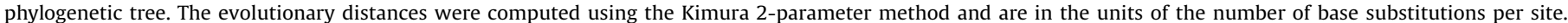

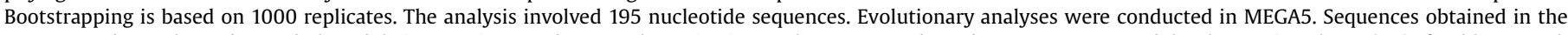

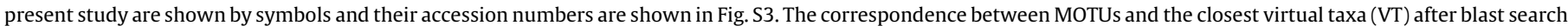
against the MaarjAM database (Öpik et al., 2010) is shown in Fig. S3 and Table 3. 
Table 3

List of the molecular taxonomic unit (MOTU) of the sequences retrived in this study and their correspondence with the closest virtual taxon (VT) after blast search against the MaarjAM database (Öpik et al., 2010). The accession number of MaarjAM type sequences is also shown.

\begin{tabular}{llll}
\hline MOTU & Code $^{*}$ & VT & Accession number \\
\hline Fun1_AMASS & 8 & VT065/067 & Y17635 \\
Glo1_AMASS & 1 & VT309 & FJ194511 \\
Glo2_AMASS & 2 & VT309 & FJ194511 \\
Glo3_AMASS & 6 & VT093 & EU332715 \\
Glo4_AMASS & 7 & VT219 & AM849279 \\
Glo5_AMASS & 9 & VT419 & EU340305 \\
Rhizo1_AMASS & 4 & VT090 & Y17648 \\
Rhizo2_AMASS & 5 & VT113/114 & AJ418876 \\
Sclero1_AMASS & 3 & VT310 & FJ194510 \\
Scut1_AMASS & 10 & VT049 & AF074340 \\
Uncult1_AMASS & 11 & VT242/151 & AB015052 \\
\hline
\end{tabular}

Code number used in Fig. 1.

\section{Results}

3.1. Experiment 1: effect of agricultural abandonment on soil chemical parameters, roots and AM fungi

\subsubsection{Soil chemical parameters, root dry weight and AM fungal root colonization}

Fifteen years of agricultural abandonment (Aband) did not significantly modify soil quality, as measured by its main chemical parameters, compared with maize cultivation (Cult), except for soil $\mathrm{NH}_{4}{ }^{+}$concentration which was around three-fold lower in the Aband than in the Cult (Table 1). However, it is noteworthy to highlight an increasing trend in the Aband soil organic matter content, which increased by $9 \%$ in comparison with the Cult, as well as other chemical parameters, such as the $P_{\text {tot }}$ and $P_{\text {avail, }}$ which increased by $8 \%$ and $5 \%$, respectively.

As regards roots, DW values were not significantly different between land uses, whereas AM fungal root colonization was significantly higher (30\%) in the Aband than in the Cult (Table 2).

\subsubsection{AM fungal diversity}

The PCR primer pair NS31/AM1, which targets the $3^{\prime}$ end of the SSU rRNA gene $(\approx 550 \mathrm{bp})$, was used to amplify and screen the clone libraries obtained from the 12 crude DNA extracts of field root and soil samples. A total of 366 clones were screened and 270 showed the expected AM fungal band length. 132 positive clones were obtained from the Aband (63 and 69 from root $(R)$ and soil samples (S), respectively) and 138 positive clones were obtained from the Cult (65 and 73 from R and S, respectively). After BLAST checking, about $40 \%$ of the sequences were excluded due to sequencing errors or PCR primer unspecificity.

The obtained sequences were grouped into 11 different AM fungal molecular operational taxonomic units (MOTUs) (a total of seven and eight in the Aband and the Cult, and six and eight in roots and soil, respectively), which were phylogenetically affiliated

\section{Table 4}

Arbuscular mycorrhizal (AM) fungal molecular operational taxonomic unit (MOTU) richness and Shannon $\left(\mathrm{H}^{\prime}\right)$ index within the native plant species roots and the soil of abandoned agricultural peaty soils (Aband) and within the maize roots and the soil of a maize cultivation (Cult).

\begin{tabular}{llllll}
\hline & \multicolumn{2}{l}{ Roots } & & \multicolumn{2}{l}{ Soil } \\
\cline { 2 - 3 } \cline { 5 - 6 } Parameter & Aband & Cult & & Aband & Cult \\
\hline MOTU richness & $4.3 \pm 1.7^{*}$ & $1.7 \pm 0.3 \mathrm{~A}$ & & $3.3 \pm 0.3 \mathrm{a}$ & $6.0 \pm 0.6 \mathrm{~b} \mathrm{~B}$ \\
Shannon index $\left(\mathrm{H}^{\prime}\right)$ & $1.1 \pm 0.5$ & $0.4 \pm 0.2 \mathrm{~A}$ & & $1.0 \pm 0.1$ & $1.5 \pm 0.2 \mathrm{~B}$ \\
\hline
\end{tabular}

\footnotetext{
Values are means \pm SE of three field replicates for each treatment.Values in the same row followed by different small letters are statistically different between land uses, according to ANCOVA $(P<0.05)$.
}

to Funneliformis sp. (Fun1_AMASS), five different Glomus spp. (from Glo1_AMASS to Glo5_AMASS), two Rhizophagus sp. (Rhizo1_AMASS and Rhizo2_AMASS), Sclerocystis sp. (Sclero1_AMASS), Scutellospora sp. (Scut1_AMASS) and an uncultured Glomeromycota (Uncult1_AMASS) (Fig. 1; Fig. S5). The correspondence between our MOTUs and the closest (similarity higher than 99\%) VT after blast search against the MaarjAM database is shown in Table 3. Three out of eleven MOTUs, although three were doubletons (Glo5_AMASS, Rhizo1_AMASS and Scut1_AMASS), were considered for further analyses.

The rarefaction curves showing the relation between the number of sequences and the number of observed AM fungal MOTUs retrieved from roots and soil of the Aband and the Cult (Fig. S6) demonstrated that the sampling effort was sufficient as the accumulation curves reached the asymptote.

As shown in the pie charts in Fig. 1, three AM fungal MOTUs were exclusively retrieved in the Aband: Fun1_AMASS in the soil and the others (Scut1_AMASS and Uncult1_AMASS) within the roots. Four AM fungal MOTUs were only found in the soil of the Cult (Glo2_AMASS, Glo5_AMASS, Rhizo1_AMASS and Sclero1_AMASS). By contrast, Rhizo2_AMASS, Glo1_AMASS, Glo3_AMASS and Glo4_AMASS showed a ubiquitous behavior.

The MOTU richness and Shannon biodiversity index $\left(H^{\prime}\right)$ were calculated to evaluate the AM fungal community richness and diversity in the two different land-uses, considering in this way, not only the number, but also the relative proportions of taxa (Table 4). We observed a significantly lower AM fungal richness in the soil of the Aband than in the Cult. Interestingly, in the maize cultivation, the soil showed higher values of both indexes in terms of the roots. Although a differential trend was found and both diversity indexes were three-fold higher in the Aband than in the Cult, 15 years of agricultural abandonment did not significantly affect AM fungal community richness and evenness in the roots (Table 4).

pRDAs showed that land use change significantly affected only the soil AM fungal composition and structure, and that the different matrixes have different AM fungal assemblages. pRDA revealed that land use explained $87.2 \%$ (I and II axes) of the whole variance (Fig. 2a), and that its effect on the AM fungal community was significant $(P=0.036)$. As highlighted by the arrows, Glo1_AMASS and Fun1_AMASS showed a preferential presence in the Aband, Glo2_AMASS and Sclero1_AMASS in the Cult (Fig. 2a).

As regards the Cult and the Aband, RDAs showed that the different matrixes explained $89.7 \%$ and $89.2 \%$ (I and II axes) of the whole variance, respectively (Fig. 2b,c), and that their effect on the AM fungal community was significant $(P=0.002)$. As shown by the arrows, in the Cult Glo2_AMASS, Sclero1_AMASS, Glo1_AMASS, Glo4_AMASS, Glo5_AMASS and Rhizo1_AMASS are soil preferential, while Glo3_AMASS and Rhizo2_AMASS are root preferential (Fig. 2b). Also in the Aband, the arrows showed that Rhizo2_AMASS and Glo3_AMASS are preferential of the roots and that Glo1_AMASS of the soil (Fig. 2c). Interestingly, this RDA biplot highlighted that Scut1_AMASS/Uncult1_AMASS and Fun1_AMASS, exclusively present in the Aband, were preferential of the roots and of the soil, respectively.

\subsection{Experiment 2: effect of agricultural abandonment on soil $\mathrm{CO}_{2}$ flux}

\subsubsection{Soil $\mathrm{CO}_{2}$ flux measurements}

Both air and soil temperatures and soil moisture varied considerably during the monitoring period (Fig. 3a,b). From May to August, the mean air and soil temperatures ranged from $12.0^{\circ} \mathrm{C}$ to $26.6^{\circ} \mathrm{C}$ (average value over the period $21.5^{\circ} \mathrm{C}$ ) and from $16.1{ }^{\circ} \mathrm{C}$ to $30.2{ }^{\circ} \mathrm{C}$, respectively; soil moisture (\% v:v) decreased in both land uses from $27.5 \%$ to $2.2 \%$ and from $30.8 \%$ to $15.8 \%$ for the Aband and the Cult, respectively (Fig. $3 \mathrm{~b}$ ). Rs, 
(a)

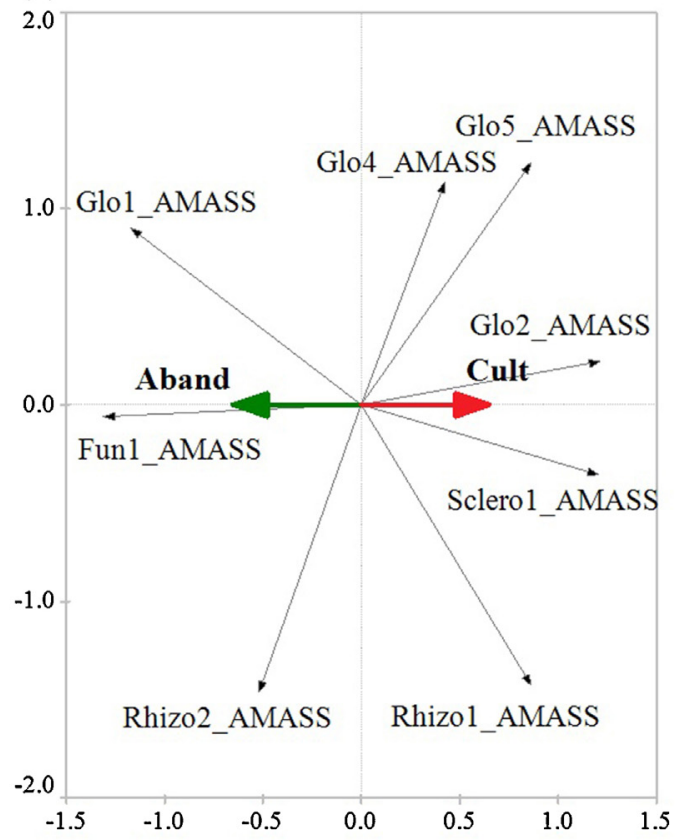

(c)

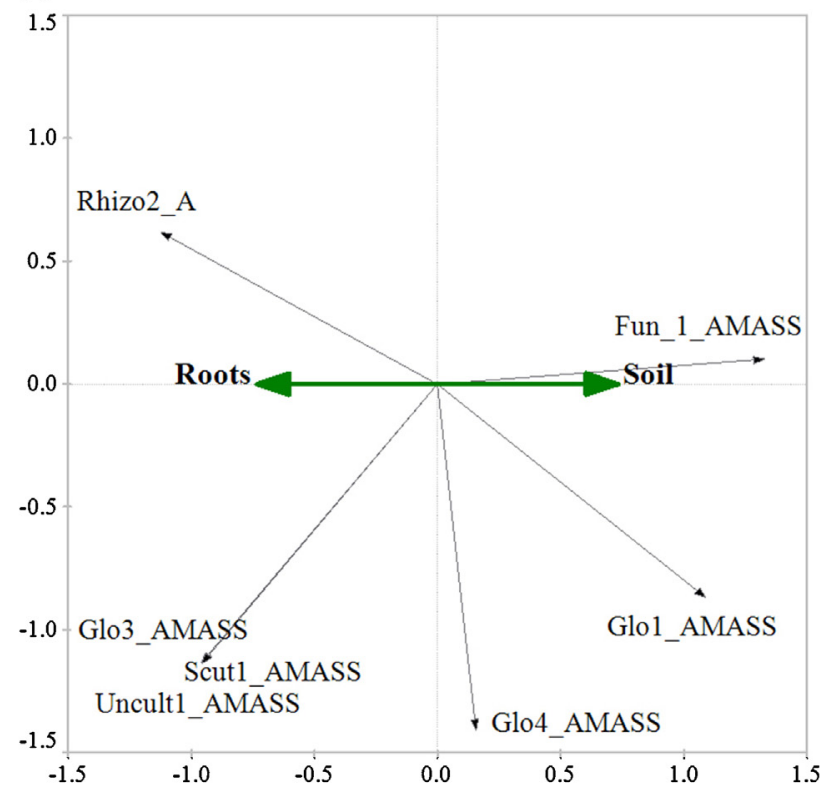

(b)

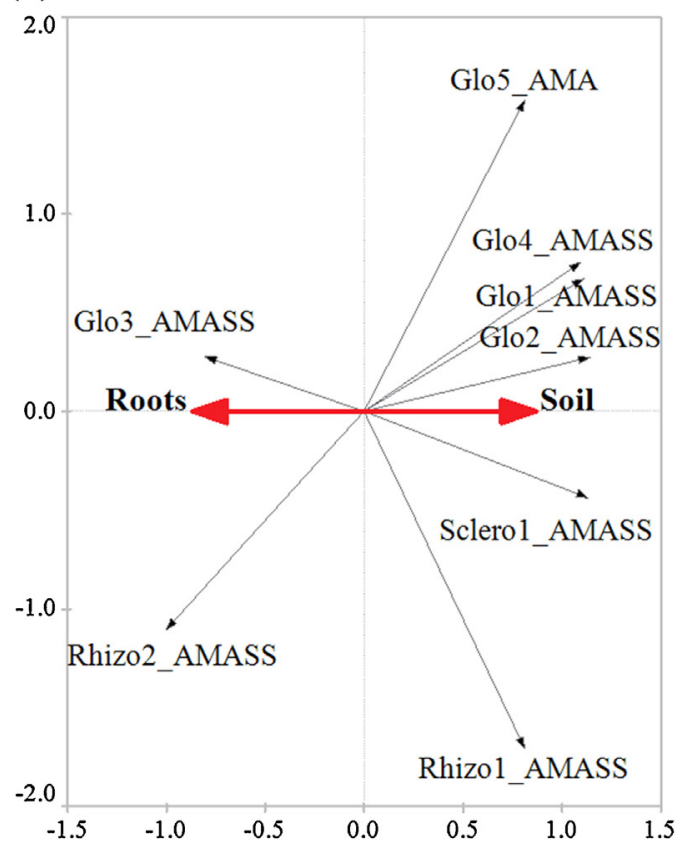

(d)

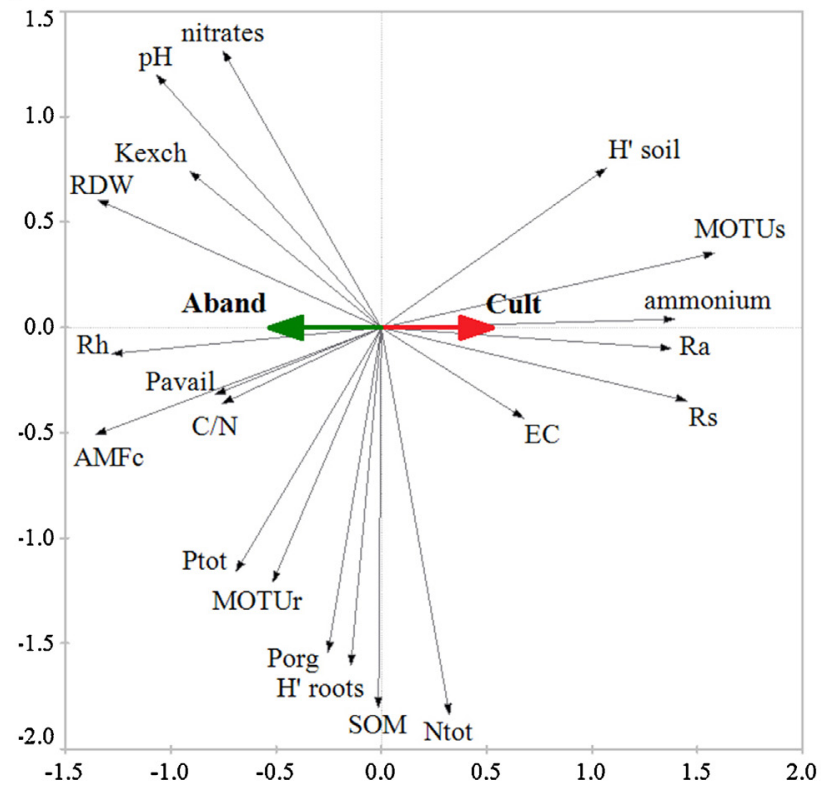

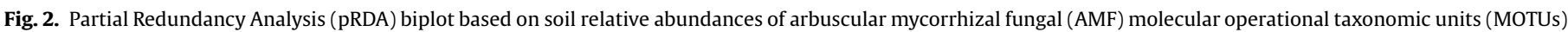

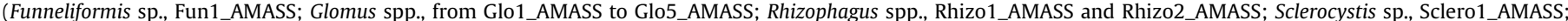

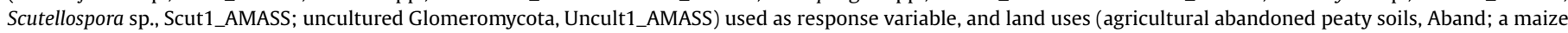

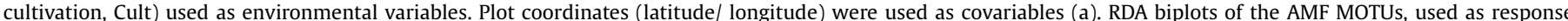

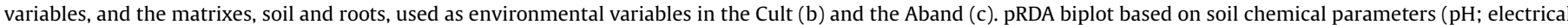

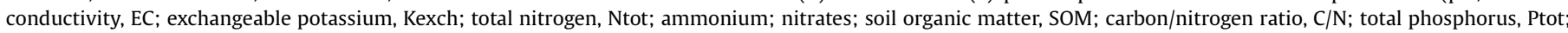

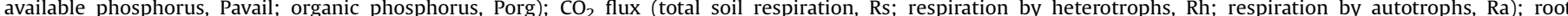

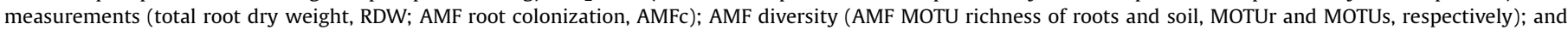

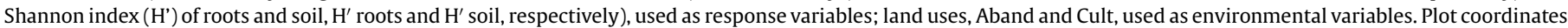

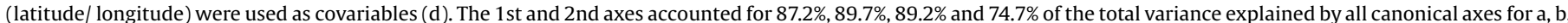

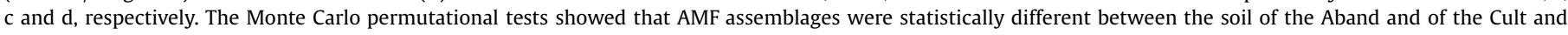

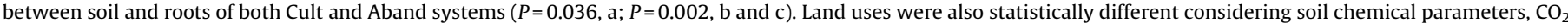
flux, root measurements and AMF diversity $(P=0.05)(d)$.

Rh and Ra steadily increased following the trend of air and soil temperatures (Fig. 3c-e). Rs ranged from 19.97 to $54.95 \mathrm{~g}$ $\mathrm{CO}_{2} \mathrm{~m}^{-2}$ day $^{-1}$ and from 9.74 to $63.35 \mathrm{~g} \mathrm{CO}_{2} \mathrm{~m}^{-2}$ day $^{-1}$ in the Aband and in the Cult, respectively, while $\mathrm{Rh}$ from 17.34 to
$35.43 \mathrm{~g} \mathrm{CO}_{2} \mathrm{~m}^{-2}$ day $^{-1}$ and from 6.79 to $29.12 \mathrm{~g} \mathrm{CO}_{2} \mathrm{~m}^{-2}$ day $^{-1}$ in the Aband and the Cult, respectively.

The Aband showed significantly higher Rs values in the first period of the monitoring (from the middle to the end of May) than 

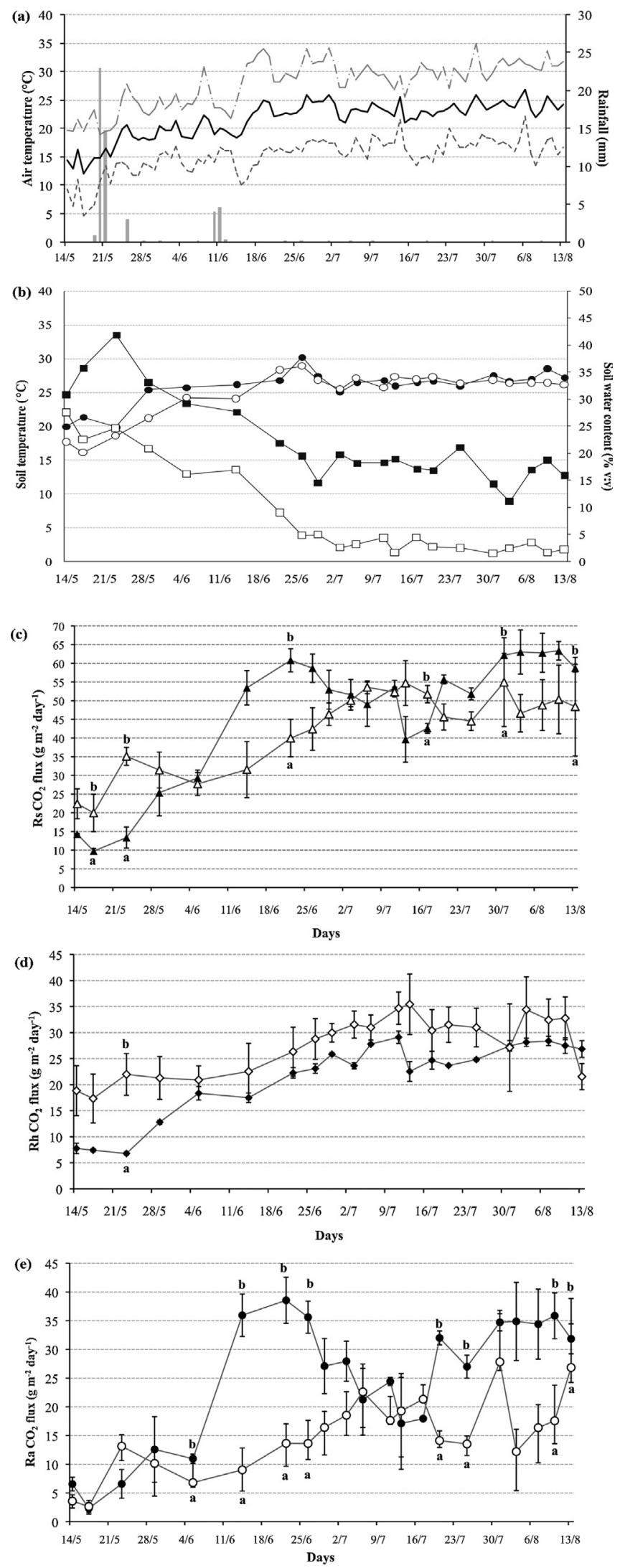

Fig. 3. Daily maximum, mean and minimum temperatures $\left({ }^{\circ} \mathrm{C}\right)$ and total rainfall $(\mathrm{mm})$ over the monitoring campaign (a). Mean soil temperature $\left({ }^{\circ} \mathrm{C}\right.$ ) (shown as circle) and moisture (\%; v:v) (shown as square) of agricultural abandoned peaty soils (open symbols; Aband) and a maize cultivation (filled symbols; Cult) (b). Soil temperature and moisture were measured outside the six blocks (see Fig. S1) used during the $\mathrm{CO}_{2}$ flux monitoring campaign. Two components of the soil $\mathrm{CO}_{2}$ fluxes,
Table 5

Comparison of three models of $\mathrm{CO}_{2}$ flux response to air temperature using different model selection criteria: the Akaike Information Criterion (AIC), the Root Mean Squared Error (RMSE) and the Adjusted R-square value (Rsd.ad). The measurements $(n=21)$ were recorded from May to August 2012 in abandoned agricultural peaty soils (Aband) and in a maize cultivation (Cult).

\begin{tabular}{|c|c|c|c|c|c|c|}
\hline \multirow{2}{*}{$\begin{array}{l}\text { Criteria } \\
\text { Rs }\end{array}$} & \multicolumn{2}{|l|}{ Q10 } & \multicolumn{2}{|l|}{ LT } & \multicolumn{2}{|l|}{ RothC } \\
\hline & Aband & Cult & Aband & Cult & Aband & Cult \\
\hline AIC & $317.9^{* *}$ & 472.9 & 317.2 & 469.9 & 365.3 & 531 \\
\hline RMSE & 9.1 & 9.8 & 9 & 9.6 & 16.2 & 15.9 \\
\hline Rsq.ad & 0.5 & 0.6 & 0.5 & 0.7 & 0.7 & 0.8 \\
\hline \multicolumn{7}{|l|}{$\mathrm{Rh}$} \\
\hline AIC & 296.6 & 331.7 & 296.6 & 326.4 & 334.5 & 384.8 \\
\hline RMSE & 7.1 & 3.2 & 7.1 & 3.1 & 11.3 & 5 \\
\hline Rsq.ad & 0.3 & 0.8 & 0.3 & 0.8 & 0.7 & 0.8 \\
\hline
\end{tabular}

* Q10: Van't Hoff's Q10 model; LT: Lloyd and Taylor model; RothC: simplified Rothamsted carbon model.

Fit model values.

the Cult, whereas, later, we observed an opposite trend. The Ra ranged from 2.63 to $27.82 \mathrm{~g} \mathrm{CO}_{2} \mathrm{~m}^{-2}$ day $^{-1}$ and from 2.33 to $38.55 \mathrm{~g}$ $\mathrm{CO}_{2} \mathrm{~m}^{-2}$ day $^{-1}$ in the Aband and the Cult, respectively. Ra in the Cult was significantly higher than in the Aband in the second halves of June and of July, while Rs only in July (Fig. 3c,e).

\subsubsection{Model selection of soil $\mathrm{CO}_{2}$ flux response to air temperature}

To calculate the cumulated values of the Rs and Rh of the soil $\mathrm{CO}_{2}$ respiration, we selected the best of the most commonly used models: Q10, LT and simplified RothC. These models were compared on the basis of AIC, RSME and Rsq. ad (Table 5). The LT model showed the best fit for Rs and Rh in the Aband and the Cult. The LT model minimized the AIC and the RSME values, while the simplified RothC model maximized the Rsq. ad values (Table 5). The LT model was thus selected for modeling the soil $\mathrm{CO}_{2}$ flux response to air temperature.

The plots of the model fitting are shown in Fig. S7. Clear relationships between Rs and Rh flux and air temperature were observed in both land uses. In the Aband significant relationships from moderate to weak were observed (Rs Rsq. ad $=0.5$; Rh Rsq. ad $=0.3 ; P<0.001$ ) (Table 5 ; Fig. S7b,d, respectively), while in the Cult strong and significant relationships were revealed (Rs Rsq. ad =0.7; Rh Rsq. ad =0.8; $P<0.001$ ) (Table 5; Fig. S7a,c, respectively).

\subsubsection{Impact of agricultural abandonment on the resilience of $\mathrm{CO}_{2}$ flux and on cumulated soil $\mathrm{CO}_{2}$ flux}

The coefficients of variation of the Rs and Rh components were significantly lower in the Aband than in the Cult, thus showing a higher fluctuation of soil $\mathrm{CO}_{2}$ flux response to air temperature (Table 6).

The curves of the Rs, Rh and Ra cumulated $\mathrm{CO}_{2}$ fluxes are shown in Fig. 4. In the Aband, Rs and Ra cumulated $\mathrm{CO}_{2}$ flux $(3999 \pm 76$ $\mathrm{g} \mathrm{m}^{-2}$ period $^{-1}$ and $1419 \pm 64 \mathrm{~g} \mathrm{~m}^{-2}$ period ${ }^{-1}$, respectively) was significantly lower than in the Cult $\left(4360 \pm 43 \mathrm{~g} \mathrm{~m}^{-2}\right.$ period $^{-1}$ and $2316 \pm 51 \mathrm{~g} \mathrm{~m}^{-2}$ period $^{-1}$, respectively) (Fig. 4). Rs and Ra cumulated soil $\mathrm{CO}_{2}$ flux variations, calculated as ((Aband-Cult)/

soil respiration (Rs; shown as triangle) (c), respiration by heterotrophs (Rh; shown $\mathrm{u}-$ as diamond)(d) were measured in the two different land uses Aband vs Cult (open ${ }^{1-}$ and filled symbols, respectively). Respiration by autotrophs (Ra; shown as circle)t)) was calculated as difference between Rs and Rh. The monitoring campaign ranges $\times-$ from the 14th of May to the 13th of August 2012 with one or two soil $\mathrm{CO}_{2}$ flux 1 measurements per week $(n=21)$. Values are means \pm SE of three replicate plots for 0 each land use. For each sampling date and soil $\mathrm{CO}_{2}$ flux component, statistically significant differences between land uses are shown by different letters according 0 , to ANCOVA $(P<0.05)$. 
Table 6

Coefficient of variation of the total soil respiration (Rs) and of the respiration by heterotrophs ( $\mathrm{Rh}$ ) and by autotrophs ( $\mathrm{Ra}$ ) of two land uses: abandoned agricultural peaty soils (Aband) vs a maize cultivation (Cult) over the monitoring campaign.

\begin{tabular}{lll}
\hline Parameter & \multicolumn{2}{l}{ Coefficient of variation } \\
\cline { 2 - 3 } & Aband & Cult \\
\hline CV_Rs (\%) & $23.3^{*} \mathrm{a}$ & $32.0 \mathrm{~b}$ \\
CV_Rh (\%) & $19.1 \mathrm{a}$ & $28.9 \mathrm{~b}$ \\
CV_Ra (\%) & 39.3 & 36.7 \\
\hline
\end{tabular}

Values in the same row followed by different letters are statistically different between land uses according to the Mann-Whitney nonparametric test $(P<0.05)$.

were $-8 \%$ and $-39 \%$, respectively. In contrast, the Rh component showed an opposite behavior with significantly higher values in the Aband $\left(2580 \pm 80 \mathrm{~g} \mathrm{~m}^{-2}\right.$ period $\left.^{-1}\right)$, than in the Cult $(2045 \pm 8$ $\mathrm{g} \mathrm{m}^{-2}$ period ${ }^{-1}$ ). In the Cult, the $\mathrm{Rh}$ and $\mathrm{Ra}$ soil $\mathrm{CO}_{2}$ flux partitioning was $47 \%$ and $53 \%$, respectively, whereas in the Aband it was $65 \%$ and $35 \%$, respectively.

\subsection{Main patterns of soil chemical parameters, $\mathrm{CO}_{2}$ flux and AM fungal} diversity as affected by agricultural abandonment

pRDA showed that land use explained 74.7\% (I and II axes) of the whole variance, and that its effect on soil quality parameters was significant $(P=0.05)$, as shown by the biplot arrows representing the Aband and the Cult (Fig. 2d). The biplot clearly suggested that the most discriminant variables between the two land uses were $\mathrm{NH}_{4}{ }^{+}$, soil AMF MOTU richness, Ra and Rs, which showed lower values in the Aband compared to the Cult, and Rh and AM fungal colonization, which showed higher values in the Aband than the Cult.

\section{Discussion}

In this work we assessed for the first time the long-term effect on soil quality of agricultural abandonment in a Mediterranean reclaimed peaty soil. Agricultural abandonment (Aband) was compared to an intensively cultivated peaty soil represented by continuous maize (Cult). Multivariate analyses showed that 15 years of agricultural abandonment: (i) did not affect the main soil chemical parameters, except for $\mathrm{NH}_{4}{ }^{+}$which was lower in the Aband than in the Cult; (ii) increased AM fungal root colonization and root AM fungal taxonomic diversity, but decreased soil MOTU richness; (iii) reduced soil and root respiration together with an

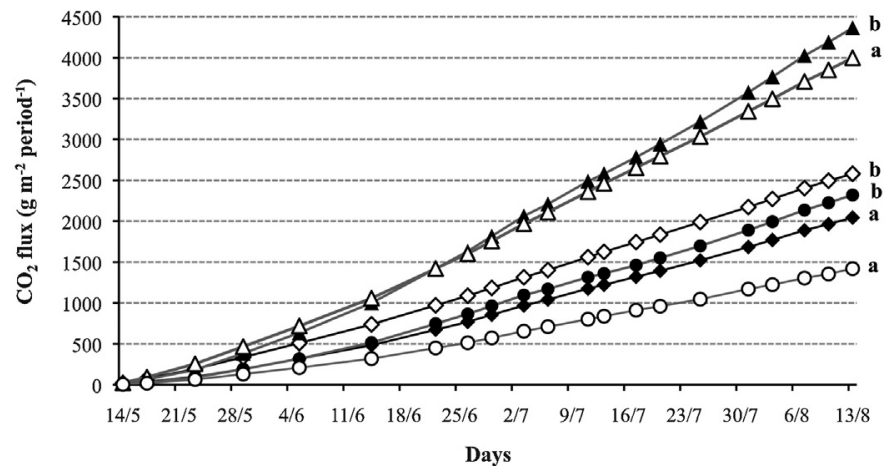

Fig. 4. Cumulated soil $\mathrm{CO}_{2}$ flux: soil respiration, $\mathrm{Rs}$ (shown as triangle); respiration by heterotrophs, Rh (shown as diamond) and respiration by autotrophs, Ra (shown as circle). The measurements ( $n=21$ ) were recorded from May to August 2012 in agricultural abandoned peaty soils (Aband; open symbols) and a maize cultivation (Cult; filled symbols). Values are means of three replicate plots for each land use. Statistically significant differences between land uses are shown by different letters according to the ANCOVA $(P<0.05)$. increase in respiration by heterotrophs; (iv) increased soil resilience to air temperature in terms of $\mathrm{CO}_{2}$ flux response.

\subsection{Effect of agricultural abandonment on soil chemical parameters, roots and AM fungi (Experiment 1)}

\subsubsection{Soil chemical parameters}

To the best of our knowledge, our work is the first one to report on the impact of the abandonment of the agricultural practices in organic drained soil. However, our results confirmed previous data detected in mineral abandoned soils which, compared to conventional farming, showed no changes in the main chemical aspects of soil quality due to fallow, land abandonment or grassland reestablishment (Liebig et al., 2004; Pellegrino et al., 2011; Bell et al., 2012).

On the other hand, our findings are in contrast with other studies reporting negative changes due to land use intensification in comparison with agricultural abandonment or grassland (Celik, 2005; Marriott et al., 2010; Gajić, 2013). These inconsistencies could be attributed to the sampling depth and to the time elapsed since land-use conversion (Liebig et al., 2004; Jinbo et al., 2007; Raiesi, 2012; Gajić, 2013). In fact differences were observed only at a $0-15 \mathrm{~cm}$ depth and already six years after abandonment. Interestingly, in line with our results, Ewing et al. (2012) found no significant changes in organic soils of total organic carbon after 15 years of crop production in reclaimed wetlands in comparison with natural wetland soils.

The fact that the only difference observed was in the soil $\mathrm{NH}_{4}{ }^{+}$ concentration could be explained by the high temporal variability of such a chemical compound (Violante, 2000) or by the closeness of the sampling to the $\mathrm{N}$ fertilization in the Cult.

Concerning the $\mathrm{C} / \mathrm{N}$ ratio, our data are in the value range reported for highly-decomposed cultivated peaty soils (Berglund et al., 2010).

\subsubsection{Root dry weight and AM fungal root colonization}

The root dry weight was in the range of those obtained for uncultivated natural fallow and maize $\left(0.04-1.8 \mathrm{mg} \mathrm{g}^{-1}\right)$ (Kothari et al., 1990; Mekonnen et al., 1997). Despite the well-known highly mycotrophic status of maize (Gavito and Varela, 1993), in our study the AM fungal root colonization of maize was lower than the natural plant species occurring in the Aband. This cannot be explained by the plant species composition in the Aband, since most of the plant species is known to be a non-mycorrhizal status (Harley and Harley, 1987). Therefore the difference is very likely due to the tillage, fertilization, mechanical and chemical weeding carried out in the Cult (Helgason et al., 1998; Vandenkoornhuyse et al., 2002; Borriello et al., 2012).

\subsubsection{AM fungal diversity}

Although in the past the importance of AMF in wetlands was not taken into account, our study on the AM fungal diversity of a Mediterranean reclaimed peaty soils was boosted by the increased awareness of their occurrence and functionality in these key ecosystems (Wolfe et al., 2007).

Root and soil MOTU richness and $H^{\prime}$ fell into a similar range to previous works (Helgason et al., 1998; Daniell et al., 2001; Hijri et al., 2006; Borriello et al., 2012), but were mostly lower than those reported by other authors (Jansa et al., 2002; Wolfe et al., 2007; Oehl et al., 2010). These inconsistencies might be due to the pedo-climatic dissimilarities, but also to the differences in detection methodologies. Root MOTU richness and $H^{\prime}$ suggested that the AM fungal diversity was not depleted by the intensification of cultivation, in line with findings in field and microcosms (Daniell et al., 2001; Johnson et al., 2004; Hijri et al., 2006). The 
higher MOTU richness in the Cult soil than in the Aband soil may be due to weed mycotrophic composition (Poaceae, Solanaceae and Phytolaccaceae).

Glomeraceae was the only family retrieved in the soil, while a member of Gigasporaceae was also detected within the roots. Our data are consistent with previous observations: Glomeraceae are mainly retrieved in agricultural soil and wetlands, while Gigasporaceae are more frequent in uncultivated or woodland sites (Helgason et al., 1998; Daniell et al., 2001; Jansa et al., 2002; Wirsel, 2004; Wolfe et al., 2007).

Within Glomeraceae, the dominance of the Rhizo2_AMASS within maize roots suggests that it can survive in agricultural conditions due to its ability to colonize the roots from mycelium fragments (Biermann and Linderman, 1983). The presence within the roots of the natural plant species of a MOTU that is phylogenetically affiliated to Scutellospora sp. is likely due to the lack of soil tillage disruption of the extraradical hyphae, which is essential for the propagation of Gigasporaceae (Jasper et al., 1993). Despite several authors highlighting the dominance of Funneliformis mosseae in arable land, grassland and also wetlands, we unexpectedly retrieved Funneliformis sp. only in the soil of the Aband, and it was not the most representative species.

\subsection{Effect of agricultural abandonment on soil $\mathrm{CO}_{2}$ flux (Experiment 2)}

\subsubsection{Soil $\mathrm{CO}_{2}$ flux measurements and cumulated values}

Differentiating the soil $\mathrm{CO}_{2}$ flux into its autotrophic and heterotrophic components is important for interpreting soil $\mathrm{CO}_{2}$ sources (Baggs, 2006; Kuzyakov, 2006). In our study, the soil $\mathrm{CO}_{2}$ sources were successfully monitored in abandoned and cultivated peaty soils using the root exclusion method. In addition, in order to fill respiration gaps and to assess the total respiration over the monitored period, the air temperature was used as an environmental variable for $\mathrm{CO}_{2}$ modeling. In fact, although some authors have modeled soil respiration using environmental parameters, such as soil water content and water table depth (Almagro et al., 2009; Correia et al., 2012; Rowson et al., 2013), most authors have found a highly significant relationship between soil or air temperature and soil respiration (Luo and Zhou, 2006; Richardson et al., 2006; Subke et al., 2006). On the basis of three different criteria, we thus selected the LT model in terms of the Q10 and the simplified RothC, in agreement also with Davidson et al. (2006) and Luo and Zhou (2006).

We used the cumulated values of the Rs, extrapolated using the LT model, to obtain the means of the daily Rs values. The calculated daily Rs fluxes of the Aband and the Cult over the monitoring period (43.47 and $47.39 \mathrm{~g} \mathrm{CO}_{2} \mathrm{~m}^{-2} \mathrm{day}^{-1}$, respectively) were twofold higher than reported by several authors as annual mean daily values (from 0.77 to $26.6 \mathrm{~g} \mathrm{CO}_{2} \mathrm{~m}^{-2}$ day $^{-1}$ ) for fens and peatlands in boreal and temperate areas (Silvola et al., 1996; KasimirKlemedtsson et al., 1997; Danevčič et al., 2010; Heinemeyer et al., 2011). This large fluxes could be explained by the fact that we monitored the spring-summer period, characterized by a warmer average temperature $\left(21.5^{\circ} \mathrm{C}\right)$ than the annual average temperature $\left(14.8^{\circ} \mathrm{C}\right)$. Although this estimation needs to be confirmed by a long-term monitoring, a strong mineralization rate is pointed out in Mediterranean peaty soils subjected to agricultural reclamation, implying a large loss of SOC and soil depth.

In addition to such factors, the not limiting soil water content could have determined larger fluxes compared to those commonly registered in mineral soils in Mediterranean areas (from 3.19 to $25.09 \mathrm{~g} \mathrm{CO}_{2} \mathrm{~m}^{-2} \mathrm{day}^{-1}$ ) (Almagro et al., 2009; Mancinelli et al., 2010; Correia et al., 2012).

With regard to the partitioning, the two respiration components showed an opposite performance since the heterotrophic component was predominant in the Aband and the autotrophic component in the Cult. An explanation for the significantly higher daily values of the Ra component in the Cult is to be find in the boost of the fine roots during the growing season of the maize crop (Rochette and Flanagan, 1997; Werth and Kuzyakov, 2009). Such effect results in a progressive increase of the flux from the sowing (first part of May) to the crop development (mid and late summer).

As suggested by Subke et al. (2006), we also compared our results on soil $\mathrm{CO}_{2}$ partitioning using the $\mathrm{Rh} / \mathrm{Rs}$ ratio. The $\mathrm{Rh} / \mathrm{Rs}$ ratio ranged from 0.65 in the Aband, with values similar to the pristine peatland to 0.47 the Cult, similar to other croplands values. These ratios were similar to those reported in Mediterranean croplands, where the mean ratio was around 0.50 (Subke et al., 2006). In contrast, our ratios were lower than those reported for boreal and temperate peatlands, ranging from 0.72 to 0.97 (Silvola et al., 1996; Wunderlich and Borken, 2012).

When considering values coming from root exclusion methods it is important to take in account the bias that this method implies. It is known that the major concern associated with this technique results in a increase in the dead root biomass in the deep collar (compared to the shallow one) that contribute to Rh and lead to an underestimation of Ra (Baggs, 2006; Subke et al., 2006; Heinemeyer et al., 2007). Moreover, some authors highlighted direct correlations between Rs and productivity and proposed that in more productive systems, as the case of Mediterranean peaty soils compared to boreal peatlands, a greater amount of assimilated $\mathrm{C}$ is allocated to $\mathrm{Ra}$, thus reducing $\mathrm{Rh} / \mathrm{Rs}$ ratio (Raich and Tufekciogul, 2000; Subke et al., 2006). Finally, another factor to take in consideration when comparing our ratio values to other ecosystems is that we monitored the spring-summer period when the Ra component, following the typical annual phenology of the vegetation, is at its maximum (Silvola et al., 1996).

\subsubsection{Resilience of the $\mathrm{CO}_{2}$ fluxes}

In agreement with our data, comparing the fluctuation of the $\mathrm{CO}_{2}$ flux in the Aband compared to the Cult, Jackson et al. (2003) reported a lower resilience in the tilled cropping systems than in the non-tilled ones. This could be explained by the higher porosity, the initial lower bulk density and the lower pore connectivity of the long-term tilled soils compared to the non-tilled soils (Silgram and Shepherd, 1999). Laliberté et al. (2010) also linked the reduction in resilience following land use intensification to plant diversity and functionality. Together with this, our maize system also showed lower plant diversity than in the abandoned peaty soil.

\section{Conclusions}

Our analysis of the chemical changes and of the peat mineralization measured using respiration by heterotrophs revealed 15 years of agricultural abandonment does not necessarily lead to the effective restoration of a Mediterranean reclaimed peatland in terms of the soil quality. The large $\mathrm{CO}_{2}$ flux that we observed demonstrates the strong degradation rate of peatwhether cultivated or abandoned-and the importance of this flux as a diffuse source of $\mathrm{CO}_{2}$ at the landscape scale. As a consequence, it highlights a strong mineralization rate in Mediterranean peaty soils subjected to reclamation, implying an important loss in SOC and in soil depth.

However, there were some positive effects in the abandonment: an increase of the diversity in terms of number of families of AMF retrieved in roots, a small reduction of total soil $\mathrm{CO}_{2}$ respiration and a lower fluctuation of soil $\mathrm{CO}_{2}$ flux response to air temperature.

We believe that our findings can be used to better understanding on how best to protect and preserve the Mediterranean peatlands. They can help to develop alternative and sustainable solutions for their restoration, supporting the importance of 
hydrological conditions (e.g., rewetting) as a major factor to trigger the restoration and to limit the mineralization rate thus controlling the subsidence effect.

\section{Acknowledgements}

This work was supported by the "Consorzio di Bonifica VersiliaMassaciuccoli" and funded by the "Regione Toscana" as a part of the project "Restoration of a Mediterranean Drained Peatland" (Restomedpeatland; https://sites.google.com/site/restomedpeatland/home). We wish to thank the technical staff of the Consorzio di Bonifica Versilia-Massaciuccoli for managing the experimental site, and Fabio Taccini and Cindy Cardenas for help in soil and $\mathrm{CO}_{2}$ samplings. Sincerest thanks to Dr. Giorgio Ragaglini and Dr. Agata Klimkowska for useful discussions, to Nikki Yeoh and Adrian John Wallwork for revising the English and to the anonymous Editor for constructive criticisms. A special thanks go to Dr. Petr Šmilauer and Prof. Marti J. Anderson for statistical advice.

\section{Appendix A. Supplementary data}

Supplementary data associated with this article can be found, in the online version, at http://dx.doi.org/10.1016/j. agee.2014.09.004.

\section{References}

Almagro, M., López, J., Querejeta, J.I., Martínez-Mena, M., 2009. Temperature dependence of soil $\mathrm{CO}_{2}$ efflux is strongly modulated by seasonal patterns of moisture availability in a Mediterranean ecosystem. Soil Biol. Biochem. 41, 594-605.

Altschul, S.F., Madden, T.L., Schäffer, A.A., Zhang, J., Zhang, Z., Miller, W., Lipman, D.J., 1997. Gapped BLAST and PSI-BLAST: a new generation of protein database search programs. Nucleic Acids Res. 25, 3389-3402.

Baggs, E.M., 2006. Partitioning the components of soil respiration: a research challenge. Plant Soil 284, 1-5.

Bell, L.W., Sparling, B., Tenuta, M., Entz, M.H., 2012. Soil profile carbon and nutrient stocks under long-term conventional and organic crop and alfalfa-crop rotations and re-established grassland. Agric. Ecosyst. Environ. 158, 156-163.

Berglund, Ö., Berglund, K., Klemedtsson, L., 2010. A lysimeter study on the effect of temperature on $\mathrm{CO}_{2}$ emission from cultivated peat soils. Geoderma 154 211-218.

Biermann, B., Linderman, R.G., 1983. Mycorrhizal roots: intraradical vesicles and extraradical vesicles as inoculum. New Phytol. 95, 97-105.

Borriello, R., Lumini, E., Girlanda, M., Bonfante, P., Bianciotto, V., 2012. Effects of different management practices on arbuscular mycorrhizal fungal diversity in maize fields by a molecular approach. Biol. Fertil. Soils 48, 911-922.

Celik, I., 2005. Land-use effects on organic matter and physical properties of soil in a southern Mediterranean highland of Turkey. Soil Till. Res. 83, 270-277.

Clarke, K.R., Gorley, R.N., 2006. PRIMER v6: User Manual/Tutorial. PRIMER-E Ltd., Plymouth.

Coleman, K., Jenkinson, D.S., 1999. ROTHC-26.3. A Model for the Turnover of Carbon in Soils. Herts, Rothamsted Research, Harpenden Hertfordshire, UK.

Coleman, B.D., 1981. On random placement and species-area relations. Math. Biosci. $54,191-215$.

Colwell, R.K., 2013. Estimates: Statistical Estimation of Species Richness and Shared Species from Samples. Version 9 and earlier. User's Guide and application. Published at: http://purl.oclc.org/estimates.

Correia, A.C., Minunno, F., Caldeira, M.C., Banza, J., Mateus, J., Carneiro, M., Wingate, L., Shvaleva, A., Ramos, A., Jongen, M., Bugalho, M.N., Nogueira, C., Lecomte, X., Pereira, J.S., 2012. Soil water availability strongly modulates soil $\mathrm{CO}_{2}$ efflux in different Mediterranean ecosystems: model calibration using the Bayesian approach. Agric. Ecosyst. Environ. 161, 88-100.

Danevčič, T., Mandic-Mulec, I., Stres, B., Stopar, D., Hacin, J., 2010. Emissions of $\mathrm{CO}_{2}$, $\mathrm{CH}_{4}$ and $\mathrm{N}_{2} \mathrm{O}$ from Southern European peatlands. Soil Biol. Biochem. 42 1437-1446.

Daniell, T.J., Husband, R., Fitter, A.H., Young, J.P.W., 2001. Molecular diversity of arbuscular mycorrhizal fungi colonising arable crops. FEMS Microb. Ecol. 36, 203-209.

Davidson, E.A., Belk, E., Boone, R.D., 1998. Soil water content and temperature as independent or confounded factors controlling soil respiration in a temperate mixed hardwood forest. Global Change Biol. 4, 217-227.

Davidson, E.A., Janssens, I.A., Luo, Y., 2006. On the variability of respiration in terrestrial ecosystems: moving beyond $Q_{10}$. Global Change Biol. 12, 154-164.

Davison, J., Öpik, M., Zobel, M., Vasar, M., Metsis, M., Moora, M., 2012. Communities of arbuscular mycorrhizal fungi detected in forest soil are spatially heterogeneous but do not vary throughout the growing season. PloS One 7, e41938.
Di Bene, C., Pellegrino, E., Debolini, M., Silvestri, N., Bonari, E., 2013. Short- and longterm effects of olive mill wastewater land spreading on soil chemical and biological properties. Soil Biol. Biochem 56, 21-30.

Doran, J.W., Parkin, T.B., 1996. Quantitative indicators of soil quality: a minimum data set. In: Doran, J.W., Jones, A.J. (Eds.), Methods for Assessing Soil Quality. SSSA Inc., Madison, WI, USA.

Ewing, J.M., Vepraskas, M.J., Broome, S.W., White, J.G., 2012. Changes in wetland soil morphological and chemical properties after 15,20 , and 30 years of agricultural production. Geoderma 179, 73-80.

Gajić, B., 2013. Physical properties and organic matter of Fluvisols under forest grassland, and 100 years of conventional tillage. Geoderma 200-201, 114-119.

Gavito, M.E., Varela, L., 1993. Seasonal dynamics of mycorrhizal associations in maize fields under low-input agriculture. Agric. Ecosyst. Environ. 45, 275-282.

Gotelli, N.J., Colwell, R.K., 2001. Estimating Species Richness. Frontiers in Measuring Biodiversity. Oxford University Press, New York.

Hall, T.A., 1999. BioEdit: a user-friendly biological sequence alignment editor and analysis program for Windows 95/98/NT. Nucl. Acid. Symp. 41, 95-98.

Harley, J.L., Harley, E.L., 1987. A check-list of mycorrhiza in the British flora-second Addenda and Errata. New Phytol. 115, 699-711.

Heinemeyer, A., Hartley, I.P., Evans, S.P., Carreira De La Fuente, J.A., Ineson, P., 2007. Forest soil $\mathrm{CO}_{2}$ flux: uncovering the contribution and environmental responses of ectomycorrhizas. Global Change Biol. 13, 1786-1797.

Heinemeyer, A., Di Bene, C., Lloyd, A.R., Tortorella, D., Baxter, R., Huntley, B., Gelsomino, A., Ineson, P., 2011. Soil respiration: implications of the plant-soil continuum and respiration chamber collar-insertion depth on measurement and modelling of soil $\mathrm{CO}_{2}$ efflux rates in three ecosystems. Eur. J. Soil Sci. 62 82-94.

Helgason, T., Daniell, T.J., Husband, R., Fitter, A.H., Young, J.P., 1998. Ploughing up the wood-wide web? Nature 394, 431.

Hence, R.J., Anderson, G., 1962. A comparative study of methods of estimating soil organic phosphate. J. Soil Sci. 13, 225-230.

Hijri, I., Sýkorová, Z., Oehl, F., Ineichen, K., Mäder, P., Wiemken, A., Redecker, D., 2006. Communities of arbuscular mycorrhizal fungi in arable soils are not necessarily low in diversity. Mol. Ecol. 15, 2277-2289.

IPCC, 2006. In: Eggleston, H.S., Buendia, L., Miwa, K., Ngara, T., Tanabe, K. (Eds.), IPCC Guidelines for National Greenhouse Gas Inventories, 4. Intergovernmental Panel on Climate Change.

IUSS Working Group WRB, 2006. World reference base for soil resources. World. Soil Resources Reports No. 103. FAO, Rome.

Jackson, L.E., Calderon, F.J., Steenwerth, K.L., Scow, K.M., Rolston, D.E., 2003. Responses of soil microbial processes and community structure to tillage events and implications for soil quality. Geoderma 114, 305-317.

Jansa, J., Mozafar, A., Anken, T., Ruh, R., Sanders, I.R., Frossard, E., 2002. Diversity and structure of AMF communities as affected by tillage in a temperate soil. Mycorrhiza 12, 225-234.

Jasper, D.A., Abbott, L.K., Robson, A.D., 1993. The survival of infective hyphae of vesicular-arbuscular mycorrhizal fungi in dry soil and interaction with sporulation. New Phytol. 124, 473-479.

Jinbo, Z., Changchun, S., Shenmin, W., 2007. Dynamics of soil organic carbon and its fractions after abandonment of cultivated wetlands in northeast China. Soil Till. Res. 96, 350-360.

Johnson, D., Vandenkoornhuyse, P.J., Leake, J.R., Gilbert, L., Booth, R.E., Grime, J.P., Young, J.P.W., Read, D.J., 2004. Plant communities affect arbuscular mycorrhizal fungal diversity and community composition in grassland microcosms. New Phytol. 161, 503-515.

Joosten, H., Clarke, D., 2002. Wise Use of Mires and Peatlands. Background and Principles Including a Fraimwork for Decision-Making. International Mire Conservation Group and International Peat Society, Saarijärvi, Finland.

Kasimir-Klemedtsson, Å., Klemedtsson, L., Berglund, K., Martikainen, P., Silvola, J., Oeema, O., 1997. Greenhouse gas emissions from farmed organic soils: a review. Soil Use Manage. 13, 245-250.

Kimura, M., 1980. A simple method for estimating evolutionary rates of base substitutions through comparative studies of nucleotide sequences. J. Mol. Evol. $16,111-120$.

Kothari, S.K., Marschnerf, H., George, E., 1990. Effect of VA mycorrhizal fungi and rhizosphere microorganisms on root and shoot morphology: growth and water relations in maize. New Phytol. 116, 303-311.

Kottek, M., Grieser, J., Beck, C., Rudolf, B., Rubel, F., 2006. World map of the KöppenGeiger climate classification updated. Meteorol. Z. 15, 259-263.

Krüger, M., Krüger, C., Walker, C., Stockinger, H., Schüssler, A., 2012. Phylogenetic reference data for systematics and phylotaxonomy of arbuscular mycorrhizal fungi from phylum to species level. New Phytol. 193, 970-984.

Kuzyakov, Y., 2006. Sources of $\mathrm{CO}_{2}$ efflux from soil and review of partitioning methods. Soil Biol. Biochem. 38, 425-448.

Laliberté, E., Wells, J.A., Declerck, F., Metcalfe, D.J., Catterall, C.P., Queiroz, C., Aubin, I., Bonser, S.P., Ding, Y., Fraterrigo, J.M., McNamara, S., Morgan, J.W., Merlos, D. S., Vesk, P.A., Mayfield, M.M., 2010. Land-use intensification reduces functional redundancy and response diversity in plant communities. Ecol. Lett. $13,76-86$.

Lepš, J., Šmilauer, P., 2003. Multivariate Analysis of Ecological Data Using CANOCO. Cambridge University Press, Cambridge.

Liebig, M., Tanaka, D., Wienhold, B., 2004. Tillage and cropping effects on soil quality indicators in the northern great plains. Soil Till. Res. 78, 131-141.

Lloyd, L., Taylor, J., 1994. On the tempearture dependence of soil respiration. Funct. Ecol. 8, 315-323.

Luo, Y., Zhou, X., 2006. Soil Respiration and the Environment. Elsevier, London. 
Mancinelli, R., Campiglia, E., Di Tizio, A., Marinari, S., 2010. Soil carbon dioxide emission and carbon content as affected by conventional and organic cropping systems in Mediterranean environment. Appl. Soil Ecol. 46, 64-72.

Marriott, C.A., Fisher, J.M., Hood, K., Pakeman, R.J., 2010. Impacts of extensive grazing and abandonment on grassland soils and productivity. Agric. Ecosyst. Environ. 139, 476-482.

McGonigle, T.P., Miller, M.H., Evans, D.G., Fairchild, G.L., Swan, J.A., 1990. A new method which gives an objective measure of colonization of roots by vesiculararbuscular mycorrhizal fungi. New Phytol. 115, 495-501.

Mekonnen, K., Buresh, R.J., Jama, B., 1997. Root and inorganic nitrogen distributions in sesbania fallow, natural fallow and maize fields. Plant Soil 188, 319-327.

Montanarella, L., Jones, R.J.A., Hiederer, R., 2006. The distribution of peatland in Europe. Mires Peat 1, 1-10.

Nelson, D.W., Sommers, L.E., 1982. Total carbon, organic carbon and organic matter, second ed. In: Page, R.H., Keeney, D.R. (Eds.), Methods of Soil Analysis, Part 2, Chemical and Microbiological Properties, Agronomy Monograph, vol. 9. American Society of Agronomy, Madison, WI, pp. 539-579.

Oehl, F. Laczko, E. Bogenrieder, A. Stahr, K, Bösch, R, van der Heijden, M., Sieverding, E., 2010. Soil type and land use intensity determine the composition of arbuscular mycorrhizal fungal communities. Soil Biol. Biochem. 42, 724-738.

Olsen, S.R., Sommers, L.E., 1982. Phosphorus, second ed. In: Page, A.L., Miller, R.H., Keeney, D.R. (Eds.), Methods of Soil Analysis, Part 2, Chemical and Microbiological Properties, Agronomy Monograph, vol. 9. American Society of Agronomy, Madison, WI, pp. 403-430.

Öpik, M., Vanatoa, A., Vanatoa, E., Moora, M., Davison, J., Kalwij, J.M., Reier, U., Zobel, M., 2010. The online database MaarjAM reveals global and ecosystemic distribution patterns in arbuscular mycorrhizal fungi (Glomeromycota). New Phytol. 188, 223-241.

Pellegrino, E., Di Bene, C., Tozzini, C., Bonari, E., 2011. Impact on soil quality of a 10 -year-old short-rotation coppice poplar stand compared with intensive agricultural and uncultivated systems in a Mediterranean area. Agric. Ecosyst. Environ. 140, 245-254.

Pellegrino, E., Turrini, A., Gamper, H.A., Cafà, G., Bonari, E., Young, J.P.W., Giovannetti, M., 2012. Establishment: persistence and effectiveness of arbuscular mycorrhizal fungal inoculants in the field revealed using molecular genetic tracing and measurement of yield components. New Phytol. 194, 810-822.

Pfadenhauer, J., Grootjans, A., 1999. Wetland restoration in Central Europe: aims and methods. Appl. Veg. Sci. 2, 95-106.

Phillips, J.M., Hayman, D.S., 1970. Improved procedures for clearing roots and staining parasitic and vesicular-arbuscular mycorrhizal fungi for rapid assessment of infection. Trans. Br. Mycol. Soc. 55, 158-161.

Picci, G., Nannipieri, P., 2002. Metodi di Analisi Microbiologica del Suolo. Franco Angeli, Roma, Italy.

Pistocchi, C., Silvestri, N., Rossetto, R., Sabbatini, T., Guidi, M., Baneschi, I., Bonari, E. Trevisan, D., 2012. A simple model to assess nitrogen and phosphorus contamination in ungauged surface drainage networks: application to the Massaciuccoli Lake Catchment, Italy. J. Environ. Qual. 41, 544-553.

Raich, J.W., Tufekciogul, A., 2000. Vegetation and soil respiration: correlations and controls. Biogeochemistry 48, 71-90.

Richardson, A.D., Braswell, B.H., Hollinger, D.Y., Burman, P., Davidson, E.A., Evans, R S., Flanagan, L.B., Munger, J.W., Savage, K., Urbanski, S.P., Wofsy, S.C., 2006.
Comparing simple respiration models for eddy flux and dynamic chamber data. Agric. For. Meteorol. 141, 219-234.

Rochette, P., Flanagan, L.B., 1997. Quantifying rhizosphere respiration in a corn crop under field conditions. Soil Sci. Soc. Am. J. 61, 466-474.

Rowson, J.G., Worrall, F., Evans, M.G., Dixon, S.D., 2013. Predicting soil respiration from peatlands. Sci. Total Environ. 442, 397-404.

Schüßler, A., Walker, C., 2010. The Glomeromycota. A species list with new families and new genera. The Royal Botanic Garden Edinburgh, The Royal Botanic Garden Kew Botanische Staatssammlung Munich. Oregon State University.

Silgram, M., Shepherd, M.A., 1999. The effects of cultivation on soil nitrogen mineralization. Adv. Agron. 65, 267-311.

Silvestri, N., Pistocchi, C., Sabbatini, T., Rossetto, R., Bonari, E., 2012. Diachronic analysis of farmers' strategies within a protected area of central Italy. Ital. J. Agron. 2, 139-145

Silvola, J., Alm, J., Ahlholm, U., Nyhanen, H., Martikainen, P.J., 1996. The contribution of plant roots to $\mathrm{CO}_{2}$ fluxes from organic soils. Biol. Fertil. Soils 23, 126-131.

Simon, L., Lalonde, M., Bruns, T.D., 1992. Specific amplification of 18 S fungal ribosomal genes from vesicular arbuscular endomycorrhizal fungi colonizing roots. Appl. Environ. Microbiol. 58, 291-295.

Smith, Read, D.J., 2008. Mycorrhizal Symbiosis, third ed. Academic Press, Amsterdam.

Soil Survey Staff, 1975. Soil taxonomy: a basic system of soil classification for making and interpreting soil surveys. USDA-SCS Agric. Handb. 436. U.S. Govt. Print. Office, Washington, DC.

Subke, J.-A., Inglima, I., Francesca Cotrufo, M., 2006. Trends and methodological impacts in soil $\mathrm{CO}_{2}$ efflux partitioning: a metaanalytical review. Global Change Biol. 12, 921-943.

Tamura, K., Peterson, D., Peterson, N., Stecher, G., Nei Kumar, M.S., 2011. MEGA 5: molecular evolutionary genetics analysis using maximum likelihood, evolutionary distance, and maximum parsimony methods. Mol. Biol. Evol. 28, 2731-2739.

ter Braak, C.J.F. Šmilauer, P., 2002. CANOCO Reference Manual and CanoDraw for Wiindows User's Guide: Software for Canonical Community Ordination (Version 4.5). Microcomputer Power, Ithaca.

Vandenkoornhuyse, P., Husband, R., Daniell, T.J., Watson, I.J., Duck, J.M., Fitter, A.H., Young, J.P.W., 2002. Arbuscular mycorrhizal community composition associated with two plant species in a grassland ecosystem. Mol. Ecol. 11, 1555-1564.

Verhoeven, J.T., Setter, T.L., 2010. Agricultural use of wetlands: opportunities and limitations. Ann. Bot. London 105, 155-163.

Violante, P., 2000. Metodi di Analisi Chimica del Suolo. Franco Angeli, Milano.

Werth, M., Kuzyakov, Y., 2009. Three-source partitioning of $\mathrm{CO}_{2}$ efflux from maize field soil by 13 C natural abundance. J. Plant Nutr. Soil Sci. 172, 487-499.

Wirsel, S.G.R., 2004. Homogenous stands of a wetland grass harbour diverse consortia of arbuscular mycorrhizal fungi. FEMS Microbiol. Ecol. 48, 129-138.

Wolfe, B.E., Mummey, D.L., Rillig, M.C., Klironomos, J.N., 2007. Small-scale spatial heterogeneity of arbuscular mycorrhizal fungal abundance and community composition in a wetland plant community. Mycorrhiza 17, 175-183.

Wunderlich, S., Borken, W., 2012. Partitioning of soil $\mathrm{CO}_{2}$ efflux in un-manipulated and experimentally flooded plots of a temperate fen. Biogeosci. Discuss. 9, 3477-3489.

Zeitz, J., Velty, S., 2002. Soil properties of drained and rewetted fen soils. J. Plant. Nutr. Soil Sci. 165, 618-626. 